ISSN: 2302-8556

E-Jurnal Akuntansi Universitas Udayana

Vol.25.2.November (2018): 1041-1069

DOI: https://doi.org/10.24843/EJA.2018.v25.i02.p09

\title{
Pengaruh Komitmen Profesional pada Kepuasan Kerja Dengan Motivasi Sebagai Variabel Moderasi
}

\section{Komang Egar Prawira ${ }^{1}$ Maria M. Ratna Sari ${ }^{2}$}

\author{
${ }^{1}$ Fakultas Ekonomi dan Bisnis Universitas Udayana (Unud), Bali, Indonesia \\ email: egarprawira@gmail.com/ Telp.082237661150 \\ ${ }^{2}$ Fakultas Ekonomi dan Bisnis Universitas Udayana (Unud), Bali, Indonesia
}

\begin{abstract}
ABSTRAK
Tujuan penelitian ini untuk menguji pengaruh komitmen professional pada kepuasan kerja dengan motivasi sebagai variabel moderasi.Penelitian ini dilakukan pada kantor konsultan pajak (KKP) di wilayah Denpasar. Sampel yang diambil sebanyak 81 responden dengan menggunakan metode purposive sampling. Pengumpulan data dilakukan dengan penyebaran kuesioner. Teknik analisis yang digunakan adalah dengan Moderated Regression Analysis (MRA).Berdasarkan hasil analisis ditemukan bahwa komitmen profesional berpengaruh positif dan signifikan terhadap kepuasan kerja pada Kantor Konsultan Pajak di Denpasar. Hasil penelitian ini juga membuktikan bahwa pengaruh komitmen profesional terhadap kepuasan kerja meningkat setelah diinteraksi dengan motivasi. Penemuan ini menunjukkan bahwa semakin tinggi komitmen profesional maka kepuasan kerja akan mengalami peningkatan, selain itu hasil penelitian ini menunjukan bahwa peran motivasi pada komitmen profesional bersifat memperkuat, artinya penerapan komitmen profesional yang semakin baik disertai dengan penerapan motivasi secara bersama-sama akan dapat meningkatkan kepuasan kerja pada Kantor Konsultan Pajak di Denpasar.

Kata kunci: komitmen professional, kepuasan kerja, motivasi.
\end{abstract}

\begin{abstract}
The purpose of this study was to examine the effect of professional commitment on job satisfaction with motivation as a moderating variable. This research was conducted at tax consultant office (KKP) in Denpasar area. Samples taken as many as 81 respondents by using purposive sampling method. Data collection was done by distributing questionnaires. The analysis technique used is with Moderated Regression Analysis (MRA). Based on the analysis results found that professional commitment has a positive and significant impact on job satisfaction at the Tax Consultant Office in Denpasar. These findings indicate that the higher the professional commitment the job satisfaction will increase, in addition the results of this study indicate that the role of motivation in professional commitment is strengthening, which means the implementation of professional commitment is better accompanied by the application of motivation together will be able to improve job satisfaction at the Tax Consultant Office in Denpasar.
\end{abstract}

Keywords: professional commitment, job satisfaction, motivation. 


\section{PENDAHULUAN}

Bidang ilmu akuntansi tidak lagi hanya dikenal dengan mengumpulkan, mengukur, mencatat, dan melaporkan informasi keuangan saja. Pengadopsian bidang ilmu lainnya seperti psikologi, sosiologi, dan psikologi sosial berkaitan dengan ilmu keperilakuan pada bidang akuntansi berhasil menghasilkan bidang ilmu baru yaitu akuntansi keperilakuan dimana bidang ini meneliti dan mempelajari pola tingkah laku manusia dengan sistem akuntansi serta dimensi sosial dan budaya manusia dalam suatu organisasi (Aryani, 2015).

Perkembangan jaman yang semakin modern ini membuat kebutuhan manusia menjadi semakin banyak. Hal tersebut membuat sebagian besar orang harus bekerja keras dan menghabiskan hampir seluruh waktunya untuk bekerja hingga mencapai kebutuhannya. Kebutuhan yang begitu banyak dapat membuat orang bekerja semakin giat dan mencapai prestasi atau justru bekerja tanpa memperhatikan norma, etika, maupun peraturan yang berlaku (Asmara, 2013).

Perilaku seseorang itu ditentukan oleh kombinasi antara kekuatan internal (internal force) yaitu faktor-faktor yang berasal dari dalam diri seseorang misalnya kemampuan, pengetahuan atau usaha, sedangkan kekuatan eksternal (eksternal force) yaitu faktor-faktor yang berasal dari luar misalnya keberuntungan, kesempatan, dan lingkungan (Fritz Heider dalam Hudayati, 2002).

Karyawan merupakan sumber daya yang menjadi salah satu aset penting bagi perusahaandalam mencapai tujuannya. Keberhasilan tersebut sangat ditentukan oleh 
ISSN: 2302-8556

E-Jurnal Akuntansi Universitas Udayana

Vol.25.2.November (2018): 1041-1069

kinerja sumber daya yang dimilikinya. Begitu pula dengan Kantor Konsultan Pajak (KKP), kinerja suatu KKP sangat ditentukan oleh kinerja konsultan pajak yang terdapat didalamnya. Kasus yang sering terjadi pada kinerja KKP yang baik dapat dirusak oleh perilaku konsultan pajak yang sulit ditangani oleh KKP. KKP merupakan organisasi yang berkecimpung di bidang jasa perpajakan. KKP memiliki tanggung jawab untuk melayani Wajib Pajak pribadi maupun badan yang ingin berkonsultasi permasalahan yang bersangkutan dengan pajak. Organisasi inipun tidak lepas dari kinerja konsultan pajaknya untuk dapat menyelesaikan permasalahan yang dihadapi Wajib Pajak.

Peran konsultan pajak diharapkan dapat membantu masyarakat dalam memenuhi hak dan kewajiban perpajakan sebagai wajib pajak. Sebagai pihak yang profesional, konsultan pajak membantu memberikan pemahaman, pembinaan serta perencanaan yang matang sehingga kewajiban perpajakan dapat terlaksana dengan baik. Bantuan konsultan pajak juga berperan dalam peningkatan kepatuhan wajib pajak dalam memahami kewajiban perpajakannya (Sormin, 2015).

Karyawan yang memiliki professional tinggi diharapkan dapat memberikan kontribusi yang signifikan dalam mencapai tujuan organisasi. Secara khusus peningkatan kinerja dan kepuasan karyawan ini merupakan tujuan yang ingin dicapai oleh setiap karyawan yang bekerja dalam suatu organisasi. Dengan demikian profesionalisme akan membantu menyelaraskan pencapaian tujuan organisasi dan tujuan personal (Cahyani dan Yuniawan, 2010). 
Profesi dibidang konsultan pajak tersebut merupakan profesi yang penuh dengan masalah dalam hal keputusan etis, karena sering dihadapkan pada kondisi dilema etis yang senantiasa mengancam profesionalitas profesinya. Terdapat kasus yang terjadi dalam profesi konsultan pajak tersebut, yakni kasus Gayus Tambunan yang melibatkan konsultan pajak Robertus Santonius dan Hendro Tirtawijaya yang membantu kliennya untuk melakukan kecurangan. Dilema etis yang dihadapi konsultan pajak membuatnya untuk melakukan keputusan yang tidak etis, karena imbalan ekonomis yang cukup material (Pratama dan Wirama, 2018). Jefriando dalam (Detik.com, 2015) profesi konsultan pajak memiliki tanggung jawab yang besar. Sebab, konsultan pajak seringkali menjadi teladan bagi para wajib pajak sehingga harus memberikan masukan yang benar. Contoh kasus diatas memperlihatkan bahwa sangat marak terjadi isu mengenai profesionalisme dimana kode etik profesinal telah dilanggar.

Pada dasarnya setiap pekerjaan yang menawarkan jasa kepada masyarakat berhubungan dengan tingkat kepercayaan masyarakat tersebut, dan kepercayaan berhubungan dengan profesionalisme. Pekerjaan yang dilakukan secara profesional akan menghasilkan pencitraan yang baik sehingga kepercayaan masyarakat meningkat. Meningkatnya kepercayaan masyarakat akan berpengaruh pada tingkat keberhasilan. Keberhasilan dan kinerja seseorang dalam suatu bidang pekerjaan banyak ditentukan oleh tingkat kompetensi, profesionalisme dan juga komitmennya terhadap bidang yang ditekuninya (Trianingsih, 2001). 
ISSN: 2302-8556

E-Jurnal Akuntansi Universitas Udayana

Vol.25.2.November (2018): 1041-1069

Menurut Asmara (2013) komitmen professional adalah tingkat loyalitas individu pada profesinya seperti yang seseorang dapat berperilaku dengan baik, maka ia harus memperhatikan etika professional yang diatur dalam kode etik. Etika professional merupakan standar perilaku seseorang professional yang dirancang untuk tujuan praktis dan idealistik sehingga mendorong perilaku seseorang yang ideal, bersifat realistis, dan dapat dipertanggungjawabkan secara hukum. Dalam suatu asosiasi profesi ditekankan akan adanya tingkat komitmen yang setinggi-tingginya yang diwujudkan dengan kerja berkualitas sekaligus sebagai jaminan keberhasilan atas tugas yang dihadapinya.

Komitmen merupakan salah satu unsur penting dalam dunia kerja, dan komitmen memiliki hubungan yang positif dengan kinerja. Komitmen merupakan keterikatan atau perjanjian suatu individu terhadap suatu hal, seperti dirinya sendiri, orang lain, lingkungan, maupun pekerjaannya. Adanya suatu komitmen dapat menjadi suatu dorongan bagi seseorang untuk bekerja dengan lebih baik. Komitmen seseorang terhadap profesinya sangatlah penting, oleh sebab itu pemahaman mengenai komitmen profesional menjadi penting agar tercipta situasi kerja yang kondusif sehingga seseorang dapat bekerja dengan efektif dan efisien. (Asmara, 2013)

Larkin (1990) dalam Trianingsih (2001) menyatakan bahwa suatu komitmen profesional pada dasarnya merupakan presepsi yang berintikan loyalitas, tekad dan harapan seseorang dengan dituntun oleh sistem nilai atau norma yang akan mengarahkan orang tersebut untuk bertindak atau bekerja sesuai prosedur-prosedur 
tertentu dalam upaya menjalankan tugasnya dengan tingkat keberhasilan yang tinggi. Seorang yang profesional akan menjalankan tugasnya dengan baik dan memperhatikan norma, kode etik, dan peraturan yang berlaku. Para profesional merasa lebih senang mengasosiasikan diri mereka dengan organisasi profesi mereka dalam melaksanakan tugas-tugasnya.

Komitmen profesional pada akhirnya akan berujung pada kepuasan kerja. Komitmen profesional akan mengarahkan orang melakukan pekerjaannya sesuai prosedur-prosedur tertentu dalam upaya menjalankan tugasnya dengan tingkat keberhasilan yang tinggi. Pekerjaan yang berkualitas tersebut akan menaikkan tingkat kepercayaan klien maupun pihak ketiga sehingga layak diberikan penghargaan, selain itu pekerjaan yang berkualitas juga akan memberikan hasil yang bernilai tinggi. Hal tersebut yang nantinya akan menimbulkan kepuasan dalam bekerja. Seseorang dengan tingkat kepuasan kerja yang tinggi memiliki perasaan yang positif mengenai pekerjaannya, sedangkan seseorang dengan level yang rendah memiliki perasaan negatif (Robbins, 2015).

Davis dan John (1994:105) menyatakan bahwa kepuasan kerja adalah seperangkat perasaan pegawai tentang menyenangkan atau tidaknya pekerjaan mereka. Pegawai yang bergabung dalam suatu organisasi akan membawa serta seperangkat keinginan, kebutuhan, hasrat, dan pengalaman masa lalu yang menyatu membentuk harapan kerja. Kepuasan kerja menunjukkan kesesuaian antara harapan seseorang yang timbul dan imbalan yang disediakan pekerjaan jadi kepuasan kerja juga berkaitan erat dengan teori keadilan, perjanjian psikologis, dan motivasi. 
ISSN: 2302-8556

Motivasi merupakan salah satu faktor penyebab yang paling penting dari munculnya kepuasan kerja. Motivasi merupakan suatu dorongan yang timbul dari dalam diri seseorang untuk mencapai tujuan tertentu. Umumnya karyawan selalu memiliki dua hal yang menjadi motivasi kerja, yaitu pertama adalah kebutuhan yang harus dipenuhi dan yang kedua adalah harapan bahwa pekerjaan yang dijalani dapat memberikan hasil yang bernilai tinggi.

Menurut Trianingsih dalam Asmara (2013) motivasi adalah sesuatu yang memulai gerakan, sesuatu yang membuat orang bertindak atau berperilaku dalam cara-cara tertentu. Adapun motivasi pada seseorang itu tergantung pada kekuatan dari motivasi itu sendiri, seberapa kuat motivasi seseorang untuk mencapai suatu tujuan. Adanya suatu komitmen profesional yang didukung oleh motivasi yang merupakan dorongan dari dalam diri seseorang yang akan meningkatkan semangat (passion) dalam bekerja akan dapat meningkatkan kepuasan kerja seseorang.

Penelitian mengenai akuntansi keperilakuan selalu menarik untuk dilakukan. Penelitian mengenai kepuasan kerja telah banyak dilakukan sebelumnya diantaranya dilakukan oleh Trianingsih (2001) dan yang dilakukan oleh Badjuri (2009) memperoleh hasil yang sama, dimana komitmen organisasional dan profesional berpengaruh terhadap kepuasan kerja baik secara langsung maupun secara tidak langsung melalui motivasi. Berbeda dengan penelitian yang dilakukan oleh Tranggono dan Andi (2008) memperoleh hasil bahwa komitmen organisasional dan profesional berpengaruh secara langsung pada kepuasan kerja, namun motivasi sebagai variabel intervening memiliki pengaruh yang kecil terhadap kepuasan kerja 
sehingga variabel motivasi diabaikan. Berbeda dengan penelitian yang dilakukan Wijayanti (2008) yang memperoleh hasil dimana komitmen profesional tidak berpengaruh terhadap kepuasan kerja, motivasi tidak memoderasi hubungan antara komitmen profesional terhadap kepuasan kerja. Inkonsistensi dari penelitian terdahulu menjadi alasan mengapa peneliti tertarik untuk mencoba menganalisis kembali hubungan antara "pengaruh komitmen profesional pada kepuasan kerja dengan motivasi sebagai variabel moderasi”. Dengan kantor konsultan pajak (KKP) di Denpasar sebagai tempat penelitian disebabkan karena pada kantor konsultan tingkat perputaran karyawan cepat, karyawan lebih cepat berhenti ketika mereka sudah memiliki pengalaman yang cukup dan diduga disebabkan oleh tingkat kepuasan kerja.

Berdasarkan Latar belakang diatas, rumusan masalah dalam penelitian ini adalah 1) Apakah komitmen profesional mempunyai pengaruh pada kepuasan kerja? 2) Apakah motivasi memoderasi pengaruh komitmen profesional pada kepuasan kerja?

Teori atribusi (Attribution Theory) merupakan teori yang menjelaskan tentang perilaku seseorang. Teori atribusi mempelajari proses bagaimana seseorang mengintrepretasikan suatu peristiwa, mempelajari bagaimana seseorang menginterpretasikan alasan atau sebab perilakunya (Steers, 1998 dalam Hudayati, 2002). Teori ini mengargumentasikan bahwa perilaku seseorang itu ditentukan oleh kombinasi antara kekuatan internal (internal forces) yaitu faktor-faktor yang berasal 
ISSN: 2302-8556

E-Jurnal Akuntansi Universitas Udayana

Vol.25.2.November (2018): 1041-1069

dari dalam diri seseorang misalnya kemampuan, pengetahuan atau usaha; sedangkan kekuatan eksternal (eksternal forces) yaitu faktor-faktor yang berasal dari luar misalnya keberuntungan, kesempatan dan lingkungan (Fritz Heider, 1958 dalam Hudayati, 2002). Penyebab perilaku dalam persepsi sosial dikenal sebagai dispositional attribution dan situational attribution atau penyebab internal dan eksternal (Robbins dan Judge, 2008).

Disposition attribution atau penyebab internal mengacu pada aspek perilaku individu, sesuatu yang ada dalam diri seseorang seperti sifat pribadi persepsi diri, kemampuan motivasi. Situational attribution atau penyebab eksternal mengacu pada lingkungan yang mempengaruhi perilaku, seperti kondisi sosial, nilai sosial, pandangan masyarakat. Penentu atribusi atau penyebab apakah individu atau situasi dipengaruhi oleh tiga faktor Robbins (1996) (dalam Ika, 2011) a) Konsensus (consensus) perilaku yang ditunjukkan jika semua orang yang menghadapi situasi yang serupa merespon dengan cara yang sama, b) Kekhususan (distincveness) perilaku yang ditunjukkan individu berlainan dalam situasi yang berlainan. c) Konsistensi (consistency) perilaku yang sama dalam tindakan seseorang dari waktu ke waktu.

Dalam penelitian ini menggunakan disposition attribution atau penyebab internal mengacu pada perilaku individu, sesuatu yang ada dalam seseorang seperti sifat pribadi, persepsi diri, dan kemampuan motivasi. Motivasi menjadi variabel 
pemoderasi antara pengaruh komitmen profesional pada kepuasan kerja pada Kantor Konsultan Pajak di Denpasar.

Profesi konsultan pajak merupakan profesi dengan tanggung jawab yang besar sehingga menuntut praktisinya untuk menjalankan tugas dengan profesional dan sesuai dengan peraturan yang berlaku. Kepercayaan masyarakat terhadap mutu jasa konsultan pajak akan meningkat jika melakukan pekerjaan secara profesional sesuai dengan kode etik dan standar profesi. memuat lima prinsip dasar etika profesi : 1) Prinsip integritas. Setiap Praktisi harus tegas dan jujur dalam menjalin hubungan profesional dan hubungan bisnis dalam melaksanakan pekerjaannya. 2) Prinsip objektivitas. Setiap Praktisi tidak boleh membiarkan subjektivitas, benturan kepentingan, atau pengaruh yang tidak layak (undue influence) dari pihakk-pihak lain memengaruhi pertimbangan profesional atau pertimbangan bisnisnya. 3) Prinsip Kompetensi serta sikap kecermatan dan kehati-hatian profesional (proffesional competence and due care). Setiap Praktisi wajib memelihara pengetahuan dan keahlian profesionalnya pada suatu tingkatan yang dipersyaratkan secara berkesinambungan, sehingga klien atau pemberi kerja dapat menerima jasa profesional yang diberikan secara kompeten berdasarkan perkembangan terkini dalam praktik perundang-undangan dan metode pelaksanaan pekerjaan. Setiap Praktisi harus bertindak secara profesional dan sesuai dengan standar profesi dan kode etik profesi yang berlaku dalam memberikan jasa profesionalnya. 4) Prinsip kerahasiaan. Setiap Praktisi wajib menjaga kerahasiaan informasi yang diperoleh sebagai hasil dari hubungan profesional dan hubungan bisnisnya, serta tidak boleh mengungkapkan 
ISSN: 2302-8556

E-Jurnal Akuntansi Universitas Udayana

Vol.25.2.November (2018): 1041-1069

informasi tersebut kepada pihak ketiga tanpa persetujuan dari klien atau pemberi kerja, kecuali jika terdapat kewajiban untuk mengungkapkan sesuai dengan ketentuan hukum atau peraturan lainnya yang berlaku. Informasi rahasia yang diperoleh dari hubungan profesional dan hubungan bisnis tidak boleh digunakan oleh Praktisi untuk keuntungan pribadinya atau pihak ketiga. 5) Prinsip perilaku professional. Setiap Praktisi wajib mematuhi hukum dan peraturan yang berlaku dan harus menghindari semua tindakan yang dapat mendiskreditkan profesi.

Kepuasan kerja menurut Handoko dalam (Iskandar, 2014) adalah suatu keadaan emosional individu, dimana keadaaan tersebut menyenangkan atau tidak menyenangkan menurut sisi dan pandangan karyawan itu sendiri. Kepuasan kerja erat kaitannya dengan pencapaikan kinerja seseorang yang mempengaruhi prestasi kerjanya.

Davis dan John dalam (Asmara, 2013) menyatakan bahwa kepuasan kerja adalah seperangkat perasaan pegawai tentang menyenangkan atau tidaknya pekerjaan mereka. Kepuasan kerja memiliki banyak dimensi. Ia dapat mewakili sikap secara menyeluruh atau mengacu pada bagian pekerjaan sesesorang. Sebagai sekumpulan perasaan, kepuasan kerja bersifat dinamik. Kepuasan kerja adalah bagian dari kepuasan hidup. Sifat lingkungan seseorang diluar pekerjaan mempengaruhi perasaan didalam pekerjaan. Apabila seseorang puas akan pekerjaan yang dijalaninya, maka rasa senangpun akan datang, terlepas dari rasa tertekan, sehingga akan menimbulkan rasa aman dan nyaman untuk selalu bekerja dilingkungan kerjanya (Tranggono dan Andi, 2008). 
Kepuasan kerja hingga kini diyakini berkaitan dengan kinerja individu (karyawan), kelompok, yang pada gilirannya akan berkaitan dengan efektivitas organisasi secara keseluruhan. Kepuasan kerja yang tinggi sangat mempengaruhi kondisi kerja dan memberikan keuntungan nyata tidak saja bagian pekerjaan tetapi juga bagian manajemen dan organisasi (Aryani, 2015).

Komitmen profesional merupakan persepsi yang berintikan loyalitas, tekad, dan harapan seseorang dengan dituntun oleh sistem nilai atau norma yang akan mengarahkan orang tersebut untuk bertindak atau bekerja sesuai prosedur-prosedur tertentu dalam upaya menjalankan tugasnya dengan tingkat keberhasilan yang tinggi (Fatoni, 2005).

Tranggono dan Andi (2008) menyatakan komitmen profesional adalah tingkat loyalitas individu pada profesinya seperti yang telah dipersepsikan oleh individu tersebut. Agar seseorang dapat berperilaku dengan baik, maka ia harus memperhatikan etika profesional yang diatur dalam kode etik. Etika profesional yaitu standard perilaku seorang profesional yang dirancang untuk tujuan praktis dan idealistik, sehingga mendorong perilaku seseorang yang ideal, bersikap realistis, dan dapat dipertanggungjawabkan secara hukum. Dalam suatu asosiasi profesi ditekankan akan adanya tingkat komitmen yang setinggi-tingginya yang diwujudkan dengan kerja berkualitas sekaligus sebagai jaminan keberhasilan atas tugas yang dihadapinya.

Trisnaningsih yang dikutip oleh Akbar (2013) menjelaskan bahwa komitmen professional didasari oleh, pemahaman perilaku, sikap dan orientasi professional dalam melaksanakan tugas-tugas yang merupakan cerminan dari norma-norma, 
ISSN: 2302-8556

E-Jurnal Akuntansi Universitas Udayana

Vol.25.2.November (2018): 1041-1069

aturan dank ode etik profesinya. Komitmen professional merupakan tingkat loyalitas individu pada profrsinya, seperti yang dipersepsikan oleh individu tersebut (Restuningdiah, 2009).

Motivasi muncul karena adanya kebutuhan dan motivasi mendorong munculnya tindakan dalam rangka memenuhi kebutuhan tersebut. Motivasi dalam diri manusia dapat berupa motivasi internal diri dan eksternal. Motivasi internal diri merupakan motivasi yang muncul dari dalam pikiran, hati sanubari dan keinginan diri. Motivasi eksternal merupakan motivasi yang muncul karena adanya dorongan dari luar pribadi, misalnya dari orang lain dan organisasi tempat bekerja (Badjuri, 2009).

Davis dan John dalam (Asmara, 2013) menyatakan meskipun ada beberapa aktivitas manusia yang terjadi tanpa motivasi, namun hampir semua perilaku sadar memiliki motivasi, atau sebab. Kebutuhan menimbulkan potensi yang dimodifikasi oleh lingkungan seseorang dan menimbulkan keinginan tertentu. Atas pertimbangan seseorang terhadap situasinya secara menyeluruh, orang tersebut termotivasi untuk melakukan tindakan yang memenuhi kebutuhan mereka.

Setiap orang cenderung mengembangkan pola motivasi sebagai hasil dari lingkungan budaya tempat orang itu hidup. Pola ini merupakan sikap yang mempengaruhi cara orang-orang memandang pekerjaan dan menjalani kehidupan mereka. terdapat empat pola motivasi yaitu motivasi prestasi (acheivement motivation) yaitu dorongan dalam diri orang-orang untuk mengatasi segala tantangan dan hambatan dalam upaya mencapai tujuan. Motivasi afiliasi (affiliation motivation) 
yaitu dorongan untuk berhubungan dengan orang-orang atas dasar sosial. Motivasi Kompetensi (competence motivation) yaitu dorongan untuk mencapai keunggulan kerja, meningkatkan keterampilan pemecahan masalah, dan berusaha keras untuk inofatif. Motivasi kekuasaan (power motivation) yaitu dorongan untuk mempengaruhi orang-orang dan mengubah situasi.

Konsultan Pajak adalah orang yang memberikan jasa konsultasi perpajakan kepada Wajib Pajak dalam rangka melaksanakan hak dan memenuhi kewajiban perpajakannya sesuai dengan peraturan Menteri Keuangan (Peraturan Menteri Keuangan nomor. 111/PMK.03/2014). Untuk menjadi seorang konsultan pajak memang tidaklah mudah, tidak semua orang yang paham dan mengerti pajak dapat menjadi konsultan pajak, melainkan harus dengan memenuhi beberapa kualifikasi yang telah ditetapkan.

Komitmen profesional adalah tingkat loyalitas individu pada profesinya seperti seperti yang dipersepsikan oleh individu tersebut. (Larkin 1990 dalam Trianingsih 2001). Masih dari kutipan yang sama, Sri Trianingsih menyebutkan bahwa komitmen profesional yang didasari oleh pemahaman perilaku, sikap dan orientasi profesional seseorang dalam melaksanakan tugas-tugas merupakan cerminan dari norma-norma, aturan dan kode etik proofesinya. Hall (1968) dalam Sunggu (2004) menyatakan bahwa profesionalisme: (1) seorang yang profesional mempunyai kepentingan, (2) berkomitmen ke jasa barang publik, (3) kebutuhan otonomi pada persyaratan pekerjaan, (4) mendukung regulasi mandiri untuk pekerjaan mereka, (5) afiliasi dengan anggota profesinya. Sedangkan kepuasan kerja adalah sikap seseorang 
ISSN: 2302-8556

E-Jurnal Akuntansi Universitas Udayana

Vol.25.2.November (2018): 1041-1069

terhadap pekerjaan yang berasal dari persepsi mereka tentang pekerjaannya dan berpangkal dari berbagai aspek kerja seperti upah, kesempatan promosi, supervisor dan rekan sekerja. Kepuasan kerja juga berasal dari faktor lingkungan kerja, gaya supervisi, kebijakan dan prosedur, keanggotaan kelompok kerja, kondisi kerja dan tunjangan (Trianingsih : 2001).

Penelitian Trianingsih (2001) menyatakan bahwa komitmen profesional mempunyai pengaruh yang signifikan terhadap kepuasan kerja. Hasil penelitian ini juga membuktikan bahwa komitmen profesional mempunyai pengaruh secara tidak langsung terhadap kepuasan kerja dengan melalui motivasi. Penelitian tersebut didukung oleh penelitian yang dilakukan oleh Fatoni (2005) yang mengungkapkan bahwa komitmen profesional mempunyai pengaruh yang kuat dan positif terhadap kepuasan kerja auditor. Penelitian yang dilakukan oleh Tranggono dan Andi (2008) juga memperoleh hasil yang sama, komitmen profesional auditor berpengaruh signifikan terhadap kepuasan kerja auditor.

$\mathrm{H}_{1}$ : Terdapat pengaruh positif antara komitmen professional pada kepuasan kerja.

Larkin (1990 dalam Trianingsih 2001) yang dikutip oleh Wijayanti (2008) menyatakan bahwa suatu komitmen profesional pada dasarnya merupakan presepsi yang berintikan loyalitas, tekad dan harapan seseorang dengan dituntun oleh sistem nilai atau norma yang akan mengarahkan orang tersebut untuk bertindak atau bekerja sesuai prosedur-prosedur tertentu dalam upaya menjalankan tugasnya dengan tingkat keberhasilan yang tinggi. Hal ini dapat menjadikan komitmen profesional sebagai gagasan yang mendorong motivasi seseorang dalam bekerja.Motivasi merupakan 
dorongan yang timbul pada diri seseorang secara sadar atau tidak sadar untuk melakukan suatu tindakan dengan tujuan tertentu. Motivasi dapat timbul dari dalam diri individu (internal) maupun dari dari luar (eksternal). Motivasi internal adalah motivasi yang bersifat batiniah seperti sifat dan tingkat kesulitan pekerjaan. Sedangkan motivasi eksternal merupakan motivasi yang timbul karena pengaruh dari luar seperti kenaikan gaji. Dalam penelitian ini menggunakan disposition attribution atau penyebab internal mengacu pada perilaku individu, sesuatu yang ada dalam seseorang seperti sifat pribadi, persepsi diri, dan kemampuan motivasi. Komitmen profesional akan mendorong tercapainya motivasi karyawan mendapatkan pengakuan sebagai profesional sehingga akan menimbulkan kebanggaan diri, kemudian pengakuan sebagai profesional tersebut akan mendorong timbulnya kepuasan kerja (Badjuri 2009). Kepuasan kerja tidak dapat dipisahkan oleh motivasi yang seringkali merupakan harapan kerja karyawan. Gambaran yang akurat tentang hubungan ini adalah bahwa motivasi kerja menyumbang timbulnya kepuasan kerja yang tinggi (Trianingsih 2001). Penelitian sebelumnya yang dilakukan oleh Trianingsih (2001) telah menunjukkan bahwa komitmen profesional memiliki pengaruh secara tidak langsung terhadap kepuasan kerja dengan melalui motivasi.

Penelitian yang telah dilakukan sebelumnya oleh Trianingsih (2001) menunjukkan bahwa komitmen profesional memiliki pengaruh secara tidak langsung terhadap kepuasan kerja melalui motivasi. Penelitian yang dilakukan Sri Trianingsih didukung oleh penelitian yang dilakukan oleh Badjuri (2009) yang juga menunjukkan bahwa komitmen profesional mempunyai pengaruh secara tidak langsung terhadap 
ISSN: 2302-8556

E-Jurnal Akuntansi Universitas Udayana

Vol.25.2.November (2018): 1041-1069

kepuasan kerja melalui variabel motivasi. Namun dalam penelitian tersebut motivasi berperan sebagai variabel intervening. Penelitian yang dilakukan Wijayanti (2008) yang menggunakan motivasi sebagai variabel moderasi menunjukkan hasil yang berbeda dengan penelitian yang dilakukan oleh Trianingsih (2001) dan Badjuri (2009)

$\mathrm{H}_{2}$ : Motivasi memoderasi pengaruh komitmen profesional pada kepuasan kerja.

\section{METODE PENELITIAN}

Penelitian ini dilakukan pada Kantor Konsultan Pajak (KKP) yang terdapat di kota Denpasar. Tabel 1. berisi tentang daftar dan alamat KKP sebagai berikut.

Tabel 1.

Daftar Kantor KonsultanPajak di Kota Denpasar tahun 2017

\begin{tabular}{cll}
\hline No. & \multicolumn{1}{c}{ Nama Kantor Konsultan Pajak } & \multicolumn{1}{c}{ Alamat Kantor Konsultan Pajak } \\
\hline 1. & I Kadek Sumadi & Kompleks Pertokoan Genteng Biru - \\
2. & I Kadek Agus Ardika, SE, Ak & Denpasar \\
3. & Arief Satriawan, SE, Ak & Jl. Kenyeri - Denpasar \\
4. & I Wayan Sentana Gotama, SE & Jl. Teuku Umar - Denpasar \\
5. & Ketut Tarik, SE, SH, MM, Ak & Jl. Gunung Agung - Denpasar \\
6. & Ni Made Galih Masari, SE, Ak & Jl. Cok Agung Tresna - Denpasar \\
7. & I Gde Santana Bujangga & Jl. Diponogoro - Denpasar \\
8. & I Gusti Ngr Bagus Juliarta, SE, Ak & Jl. Trijata - Denpasar \\
9. & I Made Amaya, SE, Ak & Jl. Danau Tondano Sanur - Denpasar \\
10. & I Komang Yastana, SE & Jl. Cargo Permai - Denpasar \\
\hline
\end{tabular}
Sumber: Direktori IKPI (2017)

Data kualitatif dalam penelitian ini berupa jumlah konsultan pajak yang bekerja pada masing-masing kantor konsultan pajak sesuai dengan isi kuisioner meliputi jenjang pendidikan dan lama bekerja. Data kuantitatif dalam penelitian ini adalah data yang berupa angka - angka dan dapat dinyatakan dalam satuan tertentu seperti jumlah responden. Data primer dari penelitian ini yaitu jawaban-jawaban yang diberikan oleh responden atas pertanyaan - pertanyaan dalam kuisioner yang 
berhubungan dengan penelitian. Data sekunder dalam penelitian ini adalah data yang dikumpulkan dari sumber lain yaitu daftar Kantor Konsultan Pajak (KKP) yang terdapat di Denpasar. Dalam penelitian ini menggunakan populasi yaitu konsultan pajakyang bekerja pada Kantor Konsultan Pajak di Kota Denpasar.Metode yang digunakan dalam penelitian ini adalah purposive sampling. Metode purposive sampling adalah teknik pengambilan sampel sumber data dengan kriteria yang telah ditentukan (Sugiyono, 2014:116). Sesuai dengan kriteria sebagai berikut : (1) Pegawai pada kantor Konsultan Pajak di Kota Denpasar,(2)Pegawai yang memiliki pengalaman minimal 1 tahun. (3) Telah menyelesaikan penugasan minimal 1 kali.

Responden dalam penelitian ini adalah konsultan pajak yang bekerja pada KKP di Kota Denpasar. Data penelitian ini dikumpulkan melalui kuesioner yang disebarkan secara langsung ke KKP di Kota Denpasar.

Tabel 2.

Jumlah Responden Pada Kantor Konsultan Pajak di Denpasar

\begin{tabular}{clc}
\hline No. & \multicolumn{1}{c}{ Nama Kantor Konsultan Pajak (KKP) } & $\begin{array}{c}\text { Jumlah Konsultan } \\
\text { (orang) }\end{array}$ \\
\hline 1. & I Kadek Sumadi & 10 \\
2. & I Kadek Agus Ardika, SE.,Ak & 8 \\
3. & Arief Satriawan, SE., Ak & 20 \\
4. & I Wayan Sentana Gotama, SE & 5 \\
5. & Ketut Tarik, SE., SH., MM., Ak & 15 \\
6. & Ni Made Galih Masari, SE., Ak & 5 \\
7. & I Gde Santana Bujangga & 10 \\
8. & I Gusti Ngr Bagus Juliarta, SE., Ak & 6 \\
9 & I Made Amaya, SE., Ak & 10 \\
10. & I Komang Yastana, SE & 7 \\
Total & & 96 \\
\hline
\end{tabular}

Sumber: Data diolah, 2018

Metode pengumpulan data yang digunakan penelitian ini dengan menggunakan kuesioner. Kuesioner merupakan teknik pengumpulan data yang dilakukan dengan cara memberi beberapa pertanyaan atau tertulis kepada responden 
ISSN: 2302-8556

E-Jurnal Akuntansi Universitas Udayana

Vol.25.2.November (2018): 1041-1069

untuk dijawabnya (Sugiyono, 2014:199). Pengisian kuesioner menggunakan skala likert. Skala likert merupakan skala yang digunakan untuk mengujur sikap, pemdapat, dan persepsi sesorang atau sekelompok orang tentang suatu fenomena (Sugiyono, 2014:132). Kuesioner yang digunakan dalam penelitian ini diukur dengan skala likert 4 poin.

Teknik analisi data yang digunakan dalam penelitian ini adalah teknik analisis linear berganda. Analisis tersebut dapat dihitung dengan menggunakan alat bantu komputer yaitu program Statistic Package for the Social Science (SPSS). Versi 2.2.

Menurut Suyana Utama (2014:127) regresi dengan melakukan uji interaksi antar variabel sering disebut dengan Moderated Regression Analysis (MRA) merupakan aplikasi khusus regresi berganda linear dimana dalam persamaan regresinya mengandung unsur interaksi (perkalian dua atau lebih variabel independen).Analisis regresi dengan variabel moderating dilakukan melalui uji interaksi, dengan persamaan matematis sebagai berikut:

$$
\mathrm{Y}=\alpha:+\beta_{1} \mathrm{X}_{1}+\beta_{2} \mathrm{M}+\beta_{3} \mathrm{X}_{1} \mathrm{M}+\varepsilon
$$

\section{Dimana :}

$\begin{array}{ll}\mathrm{Y} & : \text { Kepuasan kerja } \\ \mathrm{X}_{1} & : \text { Komitmen profesional } \\ \mathrm{M} & : \text { Motivasi } \\ \alpha & : \text { Intercept } \\ \beta_{1}, \beta_{2}, \beta_{3} & : \text { Koefisian regresi } \\ \varepsilon & : \text { Error }\end{array}$

\section{HASIL DAN PEMBAHASAN}

Statistik deskriptif menyajikan informasi mengenai karakteristik variabel penelitian yaitu, jumlah responden, nilai minimum, nilai maksimum, nilai mean, dan standar 
deviasi. Hasil statistic deskriptif pada penelitian ini dapat dilihat pada Tabel 3. sebagai berikut.

\section{Tabel 3.}

\section{Hasil Statistik Deskriptif}

\begin{tabular}{lccccc}
\hline \multicolumn{1}{c}{ Variabel } & N & Min. & Max. & Mean & $\begin{array}{c}\text { Std. } \\
\text { Deviasi }\end{array}$ \\
Komitmen Profesional (X) & 81 & 26,00 & 57,00 & 47,77 & 4,27 \\
Motivasi (M) & 81 & 22,00 & 32,00 & 26,96 & 2,24 \\
Kepuasan Kerja (Y) & 81 & 8,00 & 16,00 & 10,76 & 1,62 \\
\hline Sumber: Data diolah, 2018 & & & & &
\end{tabular}

Berdasarkan Tabel 3. dapat disimpulkan bahwa jumlah pengamatan (N) penelitian iini berjumlah 81. Komitmen Profesional (X) memiliki nilai minimum sebesar 26,00 dan nilai maksimum sebesar 57,00 dengan nilai rata-rata sebesar 47,77. Nilai rata-rata 47,77 menunjukan bahwa sebagian besar responden cenderung menjawab setuju pada setiap item pertanyaan kuesioner variabel komitmen professional. Standar deviasi pada variabel komitmen professional adalah sebesar 4,27 yang berarti standar penyimpangan data terhadap nilai rata-ratanya adalah 4,27. Hal ini menunjukan bahwa dalam setiap tugas pemeriksaan, masing-masing konsultan pada Kantor Konsultan Pajak di Denpasar telah menerapkan komitmen profesionalnya.

Motivasi (M) memiliki nilai minimum sebesar 22,00 dan nilai maksimum sebesar 32,00 dengan nilai rata-rata sebesar 26,96. Nilai rata-rata 26,96 menunjukan bahwa sebagian besar responden cenderung menjawab setuju pada setiap item pertanyaan kuesioner variabel mitivasi. Standar deviasi pada variabel motivasi adalah sebesar 
ISSN: 2302-8556

2,24. Hal ini menunjukan bahwa dalam setiap penugasan, masing-masing konsultan pajak di Kantor Konsultan Pajak di Denpasar telah menerapkan motivasi.

Kepuasan Kerja (Y) memiliki nilai minimum sebesar 8,00 dan nilai maksimum sebesar 16,00 dengan nilai rata-rata sebesar 10,76. Nilai rata-rata 10,76 menunjukan bahwa sebagian besar responden cenderung menjawab setuju pada setiap item pertanyaan kuesioner variabel motivasi. Standar deviasi pada variabel motivasi adalah sebesar 1,62. Hal ini menunjukan bahwa dalam setiap tugas yang dikerjakan, masing-masing konsultan pajak di Kantor Konsultan Pajak di Denpasar telah puas dalam melakukan pekerjaannya.

MRA digunakan untuk mengetahui pengaruh variabel independen terhadap variabel dependennya yaitu pengaruh komitmen professional pada kepuasan kerja dengan motivasi sebagai variabel moderasi di Kantor Konsultan Pajak di Denpasar. Jenis moderasi pada penelitian ini yaitu pure moderasi. Pure moderasi merupakan variabel yang memoderasi hubungan antara variabel bebas dengan variabel terikat, dimana variabel moderasi dapat berinteraksi dengan variabel bebas tetapi tidak dapat menjadi variabel bebas. Hasil analisis regresi moderasi disajikan pada Tabel 4.9 sebagai berikut. 
Tabel 4.

Hasil Analisis Moderasi

\begin{tabular}{lccccc}
\hline \multicolumn{1}{c}{ Variabel } & \multicolumn{2}{c}{$\begin{array}{c}\text { Unstandardized } \\
\text { Coefficients } \\
\text { Std. Error }\end{array}$} & $\begin{array}{c}\text { Standar } \\
\text { Coefficients } \\
\text { Beta }\end{array}$ & t & Sig. \\
\hline (Constant) & $-0,185$ & 0,109 & & $-1,706$ & 0,092 \\
Komitmen & 0,291 & 0,105 & 0,291 & 2,765 & 0,007 \\
Profesional & & & & & \\
Motivasi & 0,040 & 0,109 & 0,040 & 0,369 & 0,713 \\
XM & 0,479 & 0,132 & 0,370 & 3,631 & 0,001 \\
F & & 10,122 & & & \\
Sig F & & 0,000 & & & \\
R Square & 0,283 & & & \\
Adjusted R Square & & 0,255 & & & \\
Sumber: Data diolah, 2018 & & &
\end{tabular}

Sumber: Data diolah, 2018

Berdasarkan Tabel 4. di atas dapat diketahui bahwa jenis variabel moderasi tersebut merupakan variabel pure moderator. Hal ini dapat ditunjukkan bahwa variabel moderasi berfungsi sebagai variabel predictor (independen) dan sekaligus juga berinteraksi dengan variabel predictor lainnya (Ghozali, 2013:225) variabel motivasi sebagai variabel moderator berpengaruh langsung pada variabel terikat (kepuasan kerja) dan sekaligus bertinteraksi dengan variabel bebas lainnya (komitmen profesional). Sehingga secara sistematis persamaan regresinya adalah sebagai berikut:

$$
Y=-0,185+0,291 X+0,040 M+0,479 X M \text { e }
$$

Berdasarkan model persamaan regresi tersebut dapat dijelaskan bahwa nilai konstanta dengan adanya moderasi sistem pengendalian intern adalah- 0,185 , artinya apabila variabel komitmen profesional dan motivasi serta interaksi antara variabel independen dengan moderasi sama dengan 0 (nol), maka kepuasan kerja sebesar 0,185 . 
ISSN: 2302-8556

E-Jurnal Akuntansi Universitas Udayana

Vol.25.2.November (2018): 1041-1069

Nilai koefisien regresi moderasi (X.M) adalah 0,479 dengan tingkat signifikansi sebesar 0,005, artinya apabila interaksi variabel komitmen profesional dengan sistem motivasi meningkat, maka variabel kepuasan kerja akan mengalami peningkatan dengan asumsi bahwa variabel bebasnya lainnya adalah konstan atau tidak mengalami perubahan.

Berdasarkan hasil Uji F pada Tabel 4. menghasilkan $F_{\text {hitung }}$ sebesar 10,122 dengan signifikansi sebesar 0,000 lebih kecil dari $\alpha=0,05$ ( $\alpha=5$ persen), yang berarti bahwa model yang digunakan dalam penelitian ini layak digunakan.

Berdasarkan Tabel 4. dapat diketahui bahwa besarnya nilai Adjusted R square sebesar 0,255 yang berarti 25,5 persen variabel kepuasan kerja karyawan dijelaskan oleh variabel komitmen profesional yang dimoderasi oleh motivasi. Sedangkan sisanya sebesar 74,5 persen dijelaskan oleh variabel lain yang tidak dimasukkan dalam model penelitian.

Uji t dilakukan untuk mengetahui apakah variabel independen berpengaruh terhadap variabel dependen. Uji $\mathrm{t}$ ini dilakukan dengan membandingkan nilai signifikan yang diperoleh dengan $\alpha=0,05$. Pengujian ini dilakukan untuk mengetahui pengaruh dari masing-masing variabel independen secara parsial terhadap variabel dependen dan dijelaskan bahwa pengujian Hipotesis berdasarkan Tabel 4. diperoleh nilai signifikansi uji t untuk variabel pengaruh komitmen professional pada kepuasan kerja sebesar 0,007lebih kecil dari $\alpha=0,05$ dan nilai koefisien regresi sebesar 0,291. 
Hal ini menunjukan bahwa komitmen profesional berpengaruh positif pada kepuasam kerja, sehingga hipotesis pertama dalam penelitian ini diterima.

Pengujian Hipotesis 2 berdasarkan Tabel 4. diperoleh nilai signifikansi uji t untuk variabel motivasi memoderasi pengaruh komitmen professionalpada kepuasan kerja 0,001 lebih kecil dari pada $\alpha=0,05$ dan nilai koefisien regresi sebesar 0,479 . Hal ini menunjukan bahwa motivasi mampu memoderasi komitmen professional pada kepuasan kerja sehingga hipotesis kedua pada penelitian ini dapat diterima.

Berdasarkan hasil analisis regresi linier berganda pada Tabel 4. di atas, setelah hipotesis ini diuji, hasilnya menunjukkan bahwa komitmen profesional berpengaruh positif dan signifikan terhadap kepuasan kerja pada Kantor Konsultan Pajak di Denpasar. Hal ini ditunjukkan dengan nilai signifikansi sebesar 0,007 yang nilainya lebih kecil dari tingkat signifikan yang ditetapkan $(\alpha=0,05)$ dan memiliki nilai koefisien sebesar 0,291. Sehingga hipotesis pertama (H1) diterima yakni komimten professional berpengaruh positif pada kepuasan kerja pada Kantor Konsultan Pajak di Denpasar. Hasil pengujian hipotesis tersebut mendukung hipotesis bahwa semakin tinggi komitmen profesional maka kepuasan kerja akan mengalami peningkatan, sebaliknya jika semakin menurun penerapan Komitmen Profesional maka kepuasan kerja juga akan mengalami penurunan. Hal ini sejalan dengan penelitian yang dilakukan oleh Trianingsih (2001) menyatakan bahwa komitmen profesional mempunyai pengaruh yang signifikan terhadap kepuasan kerja. Hasil penelitian ini juga membuktikan bahwa komitmen profesional mempunyai pengaruh secara tidak 
ISSN: 2302-8556

E-Jurnal Akuntansi Universitas Udayana

Vol.25.2.November (2018): 1041-1069

langsung terhadap kepuasan kerja dengan melalui motivasi. Penelitian tersebut didukung oleh penelitian yang dilakukan oleh Fatoni (2005) yang mengungkapkan bahwa komitmen profesional mempunyai pengaruh yang kuat dan positif terhadap kepuasan kerja auditor. Penelitian yang dilakukan oleh Tranggono dan Andi (2008) juga memperoleh hasil yang sama, komitmen profesional auditor berpengaruh signifikan terhadap kepuasan kerja auditor.

Pembahasan pengujian hipotesis berikutnya yaitu motivasi memoderasi pengaruh komitmen profesional terhadap kepuasan kerjapada Kantor Konsultan Pajak di Denpasar. Berdasarkan hasil analisis moderasi pada Tabel 4. di atas, setelah hipotesis di uji, hasilnya menunjukkan bahwa pengaruh komitmen profesional terhadap kepuasan kerja meningkat setelah diinteraksi dengan motivasi. Hal ini didukung dengan hasil analisis yang menunjukan bahwa nilai signifikansi sebesar 0,005 yang nilainya lebih kecil dari tingkat signifikan yang ditetapkan $(\alpha=0,05)$ dan memiliki koefisien betas sebesar 0,479. Dengan demikian motivasi terbukti sebagai variabel moderasi.

Hasil pengujian tersebut mengindikasikan bahwa peran moderasi variabel motivasi pada variabel komitmen profesional adalah bersifat memperkuat, artinya penerapan komitmen profesional yang semakin baik dengan diikuti oleh penerapan motivasiakan secara bersama-sama meningkatkan kepuasan kerja pada Kantor Konsultan Pajak di Denpasar. Hasil menunjukkan bahwa penerapan komitmen profesional oleh karyawan yang memiliki motivasi akan mampu meningkatkan 
kepuasan kerja pada Kantor Konsultan Pajak di Denpasar. Sesuai dengan teori atribusi yaitu disposition attribution atau penyebab internal mengacu pada kemampuan motivasi.

Hasil pengujian hipotesis ini konsisten dengan penelitian yang dilakukan oleh Trianingsih (2001) menunjukkan bahwa komitmen profesional memiliki pengaruh secara tidak langsung terhadap kepuasan kerja melalui motivasi. Penelitian yang dilakukan Sri Trianingsih didukung oleh penelitian yang dilakukan oleh Badjuri (2009) yang juga menunjukkan bahwa komitmen profesional mempunyai pengaruh secara tidak langsung terhadap kepuasan kerja melalui variabel motivasi. Namun dalam penelitian tersebut motivasi berperan sebagai variabel intervening. Penelitian

yang dilakukan Wijayanti (2008) yang menggunakan motivasi sebagai variabel moderasi menunjukkan hasil yang berbeda dengan penelitian yang dilakukan oleh Trianingsih (2001) dan Badjuri (2009).

\section{SIMPULAN}

Berdasarkan hasil analisis dan pembahasan pada bab - bab sebelumnya dari variabel komitmen profesional dan motivasi terhadap kepuasan kerja, maka dapat disimpulkan bahwa komitmen profesional berpengaruh positif dan signifikan terhadap kepuasan kerja pada Kantor Konsultan Pajak di Denpasar. Hasil ini berarti bahwa semakin baik komitmen profesional maka kepuasan kerja juga akan mengalami peningkatan. Hal ini sejalan dengan penelitian yang dilakukan oleh Trianingsih (2001) menyatakan bahwa komitmen profesional mempunyai pengaruh yang signifikan terhadap 
ISSN: 2302-8556

E-Jurnal Akuntansi Universitas Udayana

Vol.25.2.November (2018): 1041-1069

kepuasan kerja. Hasil penelitian ini juga membuktikan bahwa komitmen profesional mempunyai pengaruh secara tidak langsung terhadap kepuasan kerja melalui motivasi. Penelitian tersebut didukung oleh penelitian yang dilakukan oleh Fatoni (2005) yang mengungkapkan bahwa komitmen profesional mempunyai pengaruh yang kuat dan positif terhadap kepuasan kerja.

Motivasi mampu memoderasi pengaruh komitmen profesional terhadap kepuasan kerja pada Kantor Konsultan Pajak di Denpasar. Sesuai dengan teori atribusi yaitu disposition attribution atau penyebab internal mengacu pada kemampuan motivasi. Hasil moderasi memperkuat komitmen profesional terhadap kepuasan kerja pada Kantor Konsultan Pajak di Denpasar, itu artinya komitmen profesional dan motivasi dapat meningkatkan kepuasan kerja.

Berdasarkan simpulan penelitian di atas, disampaikan saran yang dapat menjadi pertimbangan manajemen Kantor Konsultan Pajak di Denpasar dalam memperbaiki kinerja. Adapun saran yang dapat disampaikan antara laindengan keterbatasan dari penelitian ini disarankan untuk penelitian selanjutnya menggunakan metode wawancara agar mendapatkan data yang valid dan menggambarkan kondisi sesungguhnya. Penelitian ini hanya menggunakan variabel yang berasal dari internal responden, disarankan untuk penelitian selanjutnya untuk menambahkan variabel eksternal seperti besaran gaji, gaya kepemimpinan, lingkungan kerja. 


\section{REFERENSI}

Asmara, A.A. Gde Dwi Aditya. 2013. Pengaruh Komitmen Profesional pada Kepuasan Kerja Auditor dengan Motivasi Sebagai Variabel Moderasi. Jurnal Akuntansi Universitas Udayana. Vol.6 No.2

Aryani, Komang Trisna. 2015. Pengaruh Komitmen Profesional, Kelebihan Beban Kerja, dan Konflik Peran, serta Locus Of Control pada Kepuasan Kerja Akuntan Pendidik. Jurnal Akuntansi Universitas Udayana.

Badjuri, Achmad. 2009. Pengaruh Komitmen Organisasional Dan Profesional Terhadap Kepuasan Kerja Auditor Dengan Motivasi Sebagai Variabel Intrevening. Kajian Akuntansi, 1(2), pp: 117-132

Cahyani, Nur dan Yuniawan, Ahyar 2010. Pengaruh Profesionalisme Pemeriksa Pajak, Kepuasan Kerja dan Komitmen Organisasi Terhadap Kinerja Karyawan. Jurnal Bisnis Dan Ekonomi (JBE). Universitas Diponegoro.

Davis, Keith, John W. Newstrom. 1994. Perilaku Dalam Organisasi.Jakarta : Erlangga

Direktori IkatanKonsultan Pajak Indonesia. http:www.ikpi.or.id.

Fatoni, Rizky A. 2005. Pengaruh Komitmen Profesional Terhadap Kepuasan Kerja Auditor. Skripsi Sarjana Jurusan Akuntansi pada Fakultas Ekonomi Universitas Widyatama, Bandung

Handoko T, Hani. 2006. Manajemen personalia dan Sumber Daya Manusia. Edisi 2, Yogyakarta: BPFE UGM

Hudayati, Ataina. 2002. Perkembangan Penelitian Akuntansi Keperilakuan:Berbagai Teori dan Pendekatan Yang Melandasi. JAAI, 6(2), pp: 1410-2420

Jefriando, M. 2015. Konsultan Pajak yang Seperti Ini Harusnya Masuk Neraka Paling Bawah. Detikfinance Selasa, 27/01/2015, Website: http://finance. detik.com/read/ 2015/01/27/120118/2815038/4/konsultan-pajak-yang-sepertiini-harusnya-masuk-neraka-paling-bawah

Larkin, Joseph M., Bruce A. Leauby. Early Employeements Experiences Of Accountants: Initial Placement, Job Satisfaction, And Migratory Patterns. The Review Of Accounting Information Ssystem,3(3), pp: 63-72 
ISSN: 2302-8556

E-Jurnal Akuntansi Universitas Udayana

Vol.25.2.November (2018): 1041-1069

Pratama, I Made Indra dan Dewa Gede Wirama. 2018. Locus Of Control Pemoderasi Pengaruh Intelektual, Emosional dan Spiritual pada Keputusan Etis Konsultan Pajak. E-jurnal Akuntansi Universitas Udayana

Sunggu, Anni Ompu. 2004. Pengaruh Profesionalisme Terhadap Kepuasan Kerja dan Komitmen Organisasi Dalam Peningkatan Kinerja. Tesis Sarjana Jurusan Akuntansi pada Ekonomi Universitas Diponegoro, Semarang.

Sormin, Feber. 2015. Pengaruh Manfaat Jasa Konsultan Pajak, Pengetahuan Perpajakan, Motivasi dan Persepsi Wajib Pajak teerhadap Kepatuhan Perpajakan (Studi Empiris pada Wajib Pajak Badan Manufaktur yang Terdaftar di BEI). Jurnal Maksi. 7 (2). hal. 161-179.

Trianingsih, Sri. 2001. Pengaruh Komitmen Terhadap Kepuasan Kerja Auditor: Motivasi Sebagai Variabel Moderating.Tesis Sarjana Jurusan Akuntansi pada Fakultas Ekonomi Universitas Diponegoro, Semarang.

Wijayanti, Diah. 2008. Pengaruh Komitmen Terhadap Kepuasan Kerja Auditor Internal : Motivasi Sebagai Variabel Moderating. SNA 11, Pontianak. 